\title{
Discovery of Novel Pyruvate Kinase Inhibitors Against Leishmania major Among FDA Approved Drugs Through System Biology and Molecular Docking Approach
}

\author{
Sistem Biyolojisi ve Moleküler Yerleştirme Yaklaşımı Yoluyla FDA Onaylı \\ İlaçlar Arasında Leishmania majora Karşı Yeni Piruvat Kinaz İnhibitörlerinin \\ Keşfi
}

\author{
(D) Nasrin AMIRI-DASHATAN1, (D) Mostafa REZAEI-TAVIRANI', (D) Mohammad Mehdi RANJBAR2, (D) Mehdi KOUSHKI3, \\ (D) Seyed Dawood MOUSAVI NASAB4, (D) Nayebali AHMADI1,5* \\ 1Shahid Beheshti University of Medical Sciences, Faculty of Paramedical Sciences, Proteomics Research Center, Tehran, Iran \\ 2Razi Vaccine and Serum Research Institute, Agricultural Research, Education and Extension Organization (AREEO), Karaj, Iran \\ 3Zanjan University of Medical Sciences School of Medicine, Department of Clinical Biochemistry, Zanjan, Iran \\ 4Pasteur Institute of Iran, Production and Research Complex, Department of Research and Development, Tehran, Iran \\ 5Shahid Beheshti University of Medical Sciences, Faculty of Paramedical Sciences, Department of Medical Lab Technology, Tehran, Iran
}

\begin{abstract}
Objectives: Leishmaniasis is one of the common forms of neglected parasitic diseases that cause a worldwide disease burden without any effective therapeutic strategy. Control of the disease currently relies on chemotherapy because most of the available drugs have toxic side-effects and drugresistant strains have emerged. Therefore, the development of new therapeutic strategies to treat patients for leishmaniasis has become a priority. The first step in drug discovery is to identify an effective drug target by methods such as system biology. Protein kinases are a promising drug target for different diseases. Due to lack of a functional krebs cycle in Leishmania species, they use glycolysis as the only source of ATP generation. Pyruvate kinase is the enzyme involved in the last step of glycolysis and considered as essential enzyme for the Leishmania survival.

Materials and Methods: This study sought to discover FDA approved compounds against the leishmanial pyruvate kinase protein. Our approach involved using quantitative proteomics, protein interaction networks and docking to detect new drug targets and potent inhibitors.

Results: Pyruvate kinase was determined as the potential drug target based on protein network analysis. The docking studies suggested trametinib and irinotecan with high binding energies of -10.4 and $-10.3 \mathrm{kcal} / \mathrm{mol}$, respectively, as the potential chemotherapeutic agents against $L$. major.

Conclusion: This study demonstrated the importance of integrating protein network analysis and molecular docking to identify new anti-leishmanial drugs. These potential inhibitors constitute novel drug candidates that should be tested in vitro and in vivo to determine their potential as an alternative chemotherapy in the treatment of leishmaniasis.
\end{abstract}

Key words: Leishmania major, pyruvate kinase, protein network, drug target, docking

ÖZ

Amaç: Leishmaniasis, herhangi bir etkili tedavi stratejisi olmadan dünya çapında bir hastalık yüküne neden olan ihmal edilmiş paraziter hastalıkların yaygın formlarından biridir. Mevcut ilaçların çoğu toksik yan etkilere sahip olduğundan ve ilaca dirençli suşlar ortaya çıktığından, hastalığın kontrolü şu anda kemoterapiye dayanmaktadır. Bu nedenle, leishmaniasis hastalarını tedavi etmek için yeni terapötik stratejilerin geliștirilmesi bir öncelik

*Correspondence: nayebalia@sbmu.ac.ir, Phone: +98-021-22714248, ORCID-ID: orcid.org/0000-0002-8870-7267

Received: 17.11.2020, Accepted: 11.03.2021

๑Turk J Pharm Sci, Published by Galenos Publishing House. 
haline gelmiştir. İlaç keşfinde ilk adım, sistem biyolojisi gibi yöntemlerle etkili bir ilaç hedefi belirlemektir. Protein kinazlar, farklı hastalıklar için umut verici bir ilaç hedefidir. Leishmania türlerinde fonksiyonel bir krebs döngüsü olmaması nedeniyle, ATP üretiminin tek kaynağı olarak glikoliz kullanırlar.

Gereç ve Yöntemler: Bu çalışma, leishmania piruvat kinaz proteinine karşı Gıda ve Illaç İdaresi onaylı bileşikleri keşfetmeyi amaçlamıştır. Yaklaşım, nicel proteomikler, protein etkileșim ağları ve yeni ilaç hedeflerini ve güçlü inhibitörleri tespit etmek için yerleștirmeyi içermiștir.

Bulgular: Protein ağı analizine dayalı olarak potansiyel ilaç hedefi olarak piruvat kinaz belirlenmiștir. Docking çalıșmaları, L. major'a karșı potansiyel kemoterapötik ajanlar olarak sırasıyla -10,4 ve -10,3 kcal/mol'lük yüksek bağlanma enerjilerine sahip trametinib ve irinotekanı önermiştir.

Sonuç: Bu çalışma, yeni anti-leishmanial ilaçları tanımlamak için protein ağı analizini ve moleküler yerleştirmeyi entegre etmenin önemini göstermiștir. Bu potansiyel inhibitörler, leishmaniasis tedavisinde alternatif bir kemoterapi olarak potansiyellerini belirlemek için in vitro ve in vivo olarak test edilmesi gereken yeni ilaç adaylarını oluşturmaktadır.

Anahtar kelimeler: Leishmania major, piruvat kinaz, protein ağı, ilaç hedefi, docking

\section{INTRODUCTION}

Leishmaniasis is a complex infectious disease caused by various species of the genus Leishmania, and is a serious public health problem in many tropical and subtropical regions of the world. ${ }^{1,2}$ The disease currently occurs in 12 million people and is threatening about 350 million in 98 countries worldwide. ${ }^{3}$ At least 20 different species of Leishmania are responsible for a wide spectrum of human leishmaniasis forms. ${ }^{4}$ This infectious disease is spread by the bites of the female Phlebotomus infected with metacyclic (infective) forms. Cutaneous leishmaniasis $(C L)$ is the most common form of leishmaniasis in humans mainly caused by L. major and L. tropica.

Currently, despite worldwide efforts to develop new drugs and vaccines, there are not effective vaccines against leishmaniasis. The main line of leishmaniasis treatment is chemotherapy. Pentavalent antimonials are the first choice for leishmaniasis treatment but have many limitations such as toxicity and emergence of drug resistance.,5 Alternative chemotherapeutic drugs such as amphotericin B and paromomycin are limited due to their high toxicity and cost. ${ }^{7}$ The challenges of toxicity, drug resistance and cost make it difficult to design an effective drug system. Therefore, the main challenge in the treatment of leishmaniasis is to discover highly effective drugs. Drug target identification is the first step in the complex drug discovery process. $^{8}$ An ideal target in a pathogen should be one that is necessary for survival of the pathogen, and should not be present in the mammalian host or must differ from its host homolog. Protein kinases are the main regulators of several cellular processes and have attracted much attention as potential drug targets to treat a wide range of infectious diseases. Although trypanosomatids generally use glycolysis as a primary source of ATP, Leishmania, in their amastigote form, use both glycolysis and aerobic oxidation. They are just less dependent on oxygen than their other form. ${ }^{9}$ In addition, Leishmania grow without glucose in vitro indicating that glucose is not their primary energy substrate. Therefore, inhibiting the glucose pathway may not have an effect on parasite growth..$^{10}$ Energy metabolism during Leishmania growth and metacyclogenesis is affected by regulated enzymes that probably respond to changes in glucose and amino acid levels in the culture medium. ${ }^{10}$

The unique location of glycolytic enzymes in glycosomes in Leishmania provides them with specific features. ${ }^{7}$
Pyruvate kinase, an enzyme that catalyzes the conversion of phosphoenolpyruvate and ADP to pyruvate and ATP in glycolysis, plays a role in regulating cell metabolism. In these organisms pyruvate kinase plays a key regulatory role, and is unique in responding to fructose 2,6-bisphosphate as an allosteric activator.1" Given the importance of the energy production cycle and the important role of pyruvate kinase in this cycle, this enzyme could be considered as a potentially important pharmaceutical target. Also, this enzyme is necessary for survival of the parasite in the host and is different from the host homolog. 7,12

Computational techniques increase the chance of success in drug discovery and in the design of desirable lead compounds. There are several computational approaches such as proteinprotein interaction network analysis to select novel promising drug targets in different diseases. ${ }^{13-15}$ In this work, we profiled the proteomic pattern of L. major metacyclic (infective stage) by using a label-free quantitative proteomic technique (sequential window acquisition of all theoretical fragment ion spectra mass spectrometry), and predicted the protein network of L. major in the STRING database. We analyzed the predicted protein network with centrality metrics to identify essential proteins as potential drug targets using the Cytoscape software. We identified drug targets evaluated with molecular docking to present new anti-leishmanial compounds (Figure 1). The objectives of this study were to: 1) identify appropriate target protein for discovery of drugs against leishmaniasis by system biology approach, and 2) identify potential lead compounds [Food and Drug Administration (FDA) compounds] for inhibition of the target enzyme by the docking method for studying protein- ligand binding interactions.

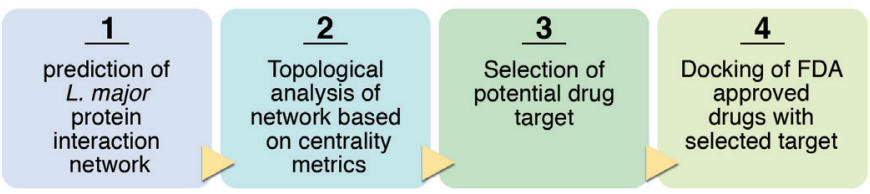

Figure 1. The framework used in the protein network and target prediction of Iranian isolate of L. major

FDA: Food and Drug Administration 


\section{MATERIALS AND METHODS}

\section{Prediction of protein network (system biology) and selection of target}

The protein profile of L. major metacyclic was used for construction of protein-protein interactions (PPIs) through text mining, co-occurrence and co-expression in the STRING database. We calculated power law fit through Network Analyzer for predicted protein network. Topological analysis of predicted protein network, based on degree and betweenness centrality, were used to identify potential drug targets using CytoHubba plugin tool in Cytoscape software.

\section{Selection of ligand dataset}

The 1948 FDA approved compounds data were retrieved from the DrugBank database (www.drugbank.ca). Refinements of the $3 \mathrm{D}$ structure of compounds were done by performing energy minimization by the HyperChem software using the molecular mechanics approach (Hypercube Inc. Gainesville, FL, USA).

\section{Target and ligand preparation}

As the protein target chosen in our study was pyruvate kinase, the most suitable 3D we used was Leishmania pyruvate kinase enzyme in interaction with Suramin drug [Protein Data Bank (PDB) ID: 3PP7] downloaded from the PDB database (www. $\mathrm{pdb}$.org). The resolution and $\mathrm{R}$-value of this structure were 2.35 $A^{\circ}$ and 0.23 , respectively. Energy optimization and correction of target protein and ligands were done using Chimera and HyperChem softwares, respectively. Briefly, water molecules and heteroatoms including ligand, cofactor, and carbohydrates were removed from the structure. Polar hydrogen atoms were then added before Kollman charges were assigned. The active sites of the target protein were evaluated based on prediction servers, inspection of $3 \mathrm{D}$ structure surface and literature review. These estimations provide the probable pocket for the binding of the substrate, which plays critical and significant roles in the enzyme function. Achieved residues in the binding pocket included: $\mathrm{Arg}_{49}, \mathrm{Thr}_{26}, \mathrm{PrO}_{29}, \mathrm{Tyr}_{59}, \mathrm{Lys}_{335}, \mathrm{His}_{54}$, and $\mathrm{Asn}_{51}$. Docking studies

In the docking study phase, compounds were searched for leishmanial pyruvate kinase inhibition activity. After the target protein and ligands preparation had been performed, docking was performed by the AutoDockVina software. ${ }^{16}$ The ligands and protein format were required to convert to the PDBQT as input format of AutoDockVina. The 3D structures of ligands were docked with the $3 D$ structure of the pyruvate kinase enzyme and their affectivity was ranked on the basis of their binding energy and hydrogen bond interactions. The docking approach uses an energy-based scoring method in which low binding energy scores represent premier protein-ligand bindings..$^{17}$ Grid box parameters were set as follows: (center_x $=27$, center_y $=18$, center_z $=40$, size $\_x=28$, size $\_y=$ 32 , size_z $=3$ ), which cover the whole protein. The Ligplot+ software was used for automatic generation of schematic diagram of protein- ligand interaction. ${ }^{18}$ LigPlot $^{+}$is a successor to the original LIGPLOT program for automatic generation of $2 \mathrm{D}$ ligand-PPI diagrams. It is run from an intuitive java interface which allows on-screen editing of the plots via mouse clickand-drag operations. The results showed some ligands which can be taken for further study on drug discovery.

\section{RESULTS AND DISCUSSION}

\section{Target selection}

We constructed a PPI map, from the results generated by mass spectrometry of L. major metacyclic protein profiling. From 144 detected proteins (results not published) in the Iranian isolate of L. major metacyclic (infective stage), we predicted a protein network with 135 nodes and 1051 interactions using the STRING database (Figure 2). Based on analysis of the topology of the network with connectivity (node degree) and betweenness centrality, we predicted potential drug targets. A measure of these centrality values has also been proposed as a new way for investigating potential drug targets. Proteins with high connectivity and betweenness centrality values are called hubs and bottlenecks, respectively. In protein networks, the proteins with high betweenness centrality value are referred to as scaffold proteins and are associated with protein essentiality more than connectivity. It has been reported that connectivity ${ }^{19}$ and betweenness centrality ${ }^{20}$ are important indices for the identification of essential proteins in protein- protein interaction networks. ${ }^{21}$ In the L. major network, we have provided a putative list of five essential (hub-bottleneck) proteins with high connectivity and betweenness centrality. Among the top five hub-bottlenecks on the basis of its major role in ATP generation in Leishmania pathogen, we selected pyruvate kinase as target for a docking study (Table 1). The 3D structure of the pyruvate kinase is available in the PDB database. Kinases are of special

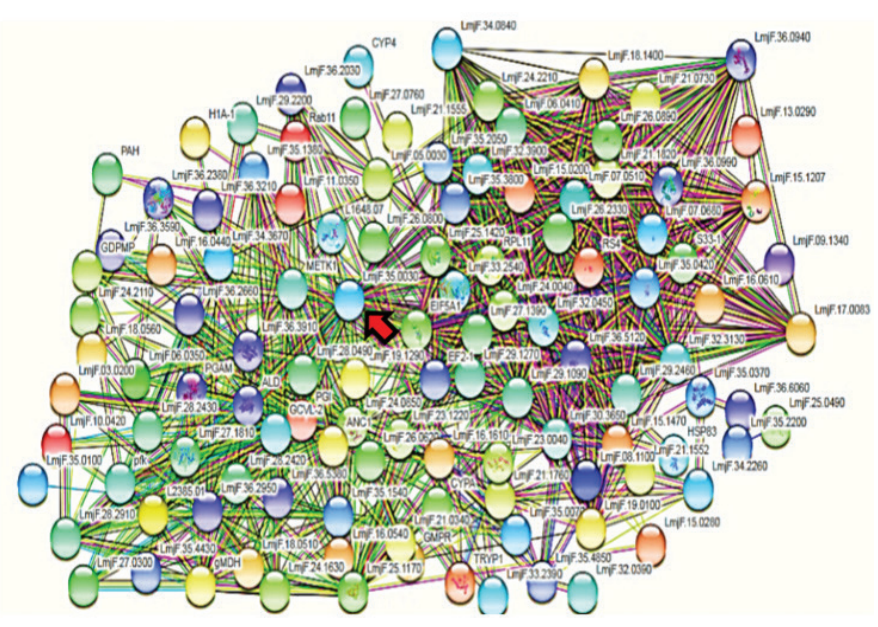

Figure 2. Protein-protein interaction network obtained by STRING v10.5. Nodes depict proteins and PPI are represented by edges in the network; interaction source of the PPI's are represented by various colors. The pyruvate kinase protein locus in PPIN is shown by arrows

PPI: Protein-protein interaction, PPIN: Protein-protein interaction network 
interest as an important category of Leishmania proteins to be considered as sources of new drug targets. ${ }^{12}$ In addition, several investigations compared the PyK crystal structure of the parasite with the PyK of other organisms. These studies reported important differences between these enzymes especially at the level of its effector site indicating distinctive regulatory attributes for the parasite enzyme, which could be a potential anti-leishmanial drug target.11,22 For example Rebollo et al. ${ }^{23}$ also selected pyruvate kinase along with other enzymes as a target protein for discovery of a new agent with potential leishmanicidal activity by virtual screening of chemical databases that all of them considered essential for the survival of Leishmania. ${ }^{24}$ In fact, the parasite needs glycolysis enzymes because they are essential for the amastigote form of parasite. So the target would stop the intracellular parasite development in the host.

\section{Docking studies}

Structure-based virtual screening was carried out to predict the binding affinity of 1388 FDA approved compounds in order to identify new inhibitors of pyruvate kinase from Leishmania. This approach involved computational docking of ligands with a receptor, followed by scoring and ranking of ligands to discove potential leads. In previous studies, docking studies of some Leishmania enzymes such as Tryparedoxin peroxidase, ${ }^{25}$ cysteine protease $A,{ }^{26} \mathrm{~N}$-myristoyltransferase, ${ }^{27}$ 6-phosphoglucono-lactonase, ${ }^{23}$ and trypanothione reductase ${ }^{28}$ were done. Tryparedoxin peroxidase and trypanothione reductase as antioxidant enzymes play an important role in parasite survival, therefore, they can be suitable options for drugs against Leishmania. For example, Kothandan et al. ${ }^{28}$ conducted a toxicology and docking study, and introduced Emetine as a potential lead compound against leishmaniasis. In the aforementioned studies, the several virtual screening databases have included Pubchem, ChemBridge and Pubchem BioAssay database. The various tools and softwares included Dock ${ }^{29}$, Gold $^{30}$, Molegro Virtual Docker ${ }^{17}$, SwissDock server ${ }^{31}$, LibDock algorithm inbuild in DSv.5, ${ }^{32}$ Sybyl 8.0 and AutoDockVina. In this study, we performed the docking assay for the first time by FDA approved compounds by AutoDockVina in order to identify pyruvate kinase inhibitors. After the compounds were screened against pyruvate kinase protein, the results were ranked based on their docking scores and the top 10 high scoring compounds are listed in Table 2. These compounds with high affinity to receptors could be considered as potential leads, which must be tested in vitro or in vivo experiments to confirm their real potential as anti-leishmanial drugs. Our results indicated that trametinib (DB08911) and irinotecan (DB00762) had the highest binding affinity to the target with -10.4 and $-10.3 \mathrm{kcal} / \mathrm{mol}$, respectively, and could provide a scaffold for further drug design efforts. Hydrogen-bonds play a crucial role in determining the specificity of ligand binding. In potential drugs from our findings, trametinib has one hydrogen bonding with a length of $2.88 \mathrm{~A}^{\circ}$ and Irinotecan has also two hydrogen bonds, one with a length of $2.99 \mathrm{~A}^{\circ}$ and the other one $3.14 \mathrm{~A}^{\circ}$. The number of hydrogen bonds of other compounds are shown in Table 2. Also, among these potential inhibitors, no side-effects have been reported for nilotinib (DB04868, Dock score: -10.1), netupitant (DB09048, Dock score: -10.1) and conivaptan (DB00872, Dock score: -9.9) in DrugBank database, rendering them valuable candidates for drug designing in future.

The protein-ligand interaction plays a crucial role in structurebased drug discovery. Based on our in silico docking analysis we suggest the following leishmanial pyruvate kinase potential drugs (trametinib, irinotecan, nilotinib, netupitant, naldemedine, eltrombopag, vumon, conivaptan, valstar and lomitapide). In this study, we took the pyruvate kinase essential protein (target) that plays a significant role in leishmaniasis and proposed the potent drugs that were used against leishmaniasis to evaluate its efficacy. These drugs can be tested in vivo and in vitro and as a lead for further validation in clinical trials. The study results would help to develop the new drugs for the leishmaniasis treatment.

This study has potential limitations. The anti-leishmanial effect of FDA-approved ligands against pyruvate kinase enzyme estimates are based only on computational methods and molecular interaction mechanism (i.e., protein interaction network and docking study). Further research involving experimental screening of compounds with high affinity and their analogues, optimization, and validation could lead to discovery of novel drugs for leishmaniasis treatment.

Table 1. Putative drug target ranked according to connectivity and betweenness centrality values in Hubba plugin in Cytoscape software. Pyruvate kinase selected in order to perform docking assay (grey color)

Hub-bottleneck proteins

\begin{tabular}{lll}
\hline Rank & Gene name & Protein name \\
\hline 1 & LmjF.28.2780 & Putative heat-shock protein hsp70 \\
\hline 2 & ENOL & Enolase \\
\hline 3 & LmjF.35.0030 & Pyruvate kinase \\
\hline 5 & LmjF.36.2030 & Chaperonin HSP60, mitochondrial \\
\hline
\end{tabular}




\section{Table 2. List of docking results of the FDA approved compounds with high binding affinity to the leishmanial pyruvate kinase inhibition}

$\begin{array}{lllllll}\text { No. Compound } & \begin{array}{l}\text { Compound } \\ \text { name }\end{array} & \begin{array}{l}\text { Binding } \\ \text { energy } \\ (\mathrm{kcal} / \mathrm{mol})\end{array} & \begin{array}{l}\text { H-bond } \\ \text { number } \\ \left(\text { length: } \mathrm{A}^{\circ}\right)\end{array} & \text { Target residues } & \text { Ligplot+ analysis } & \text { Drug structure }\end{array}$

Glu268, Il89, Val184, Phe212,

$1 \quad$ DB08911 Trametinib $\quad-10.4 \quad \begin{array}{ll}1 \\ (2.88)\end{array}$

Glu240, Ser211,

Asp264, Lys238,

Lys85, Asp145,

Gly176, Glu88,

Asn178, Pro87

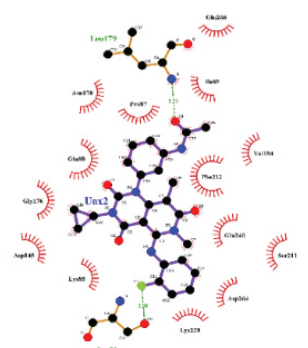

Lys467, Phe463, Gly75, Val440,

Val76, Asn432, Cys428, Ser439, Asn77, Arg22
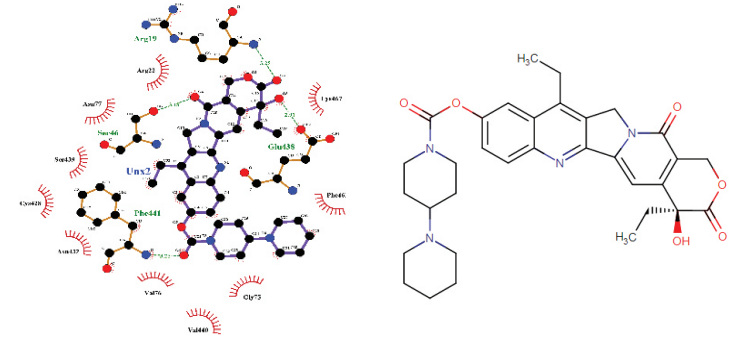

Lys394, Tyr469, Pro417, Asn17, Glu359, Gln354, Leu357, Asn358, Try360, Asn415
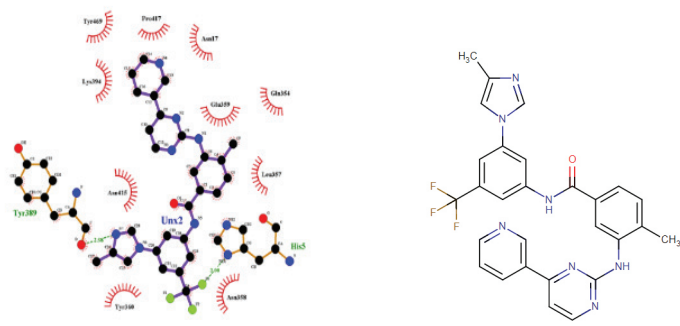

3007

Asn17, Tyr18, Arg19, Leu351, 4 DB09048 Netupitant

$-10.1$
3

(3.11, 3.12, 3.23) Asn77,Cys428, Asn432, Val76, Met45, Ser46, Gly44, Ile41, Gln42
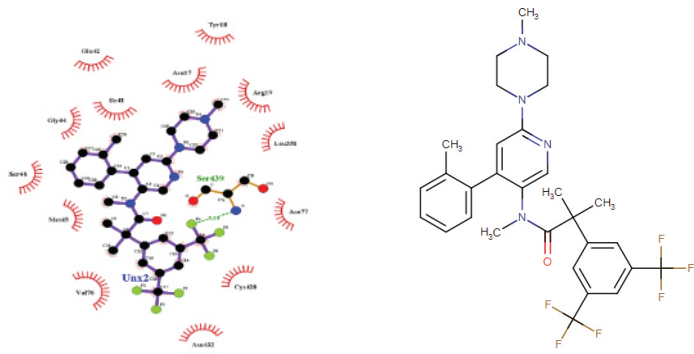

Arg49,

Thr296,Gln297, Gly263,

5 DB11691 Naldemedine $\quad-10.1$
Glu88,Glu240,

Leu186,

Asn178,Pro87,

Phe212, Val177, Ile89
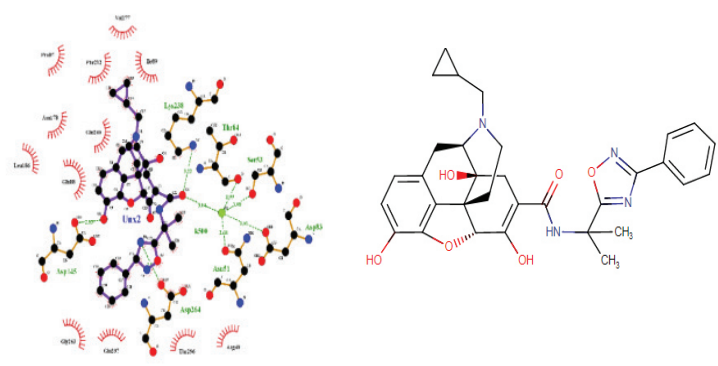
Table 2. contiuned

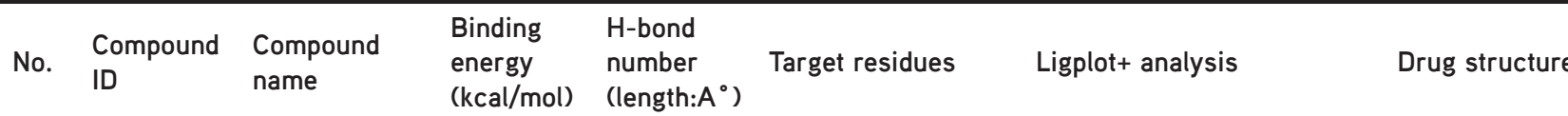

Pro417, Ala16, Glu359,

$6 \quad$ DB06210 Eltrombopag $\quad-10.0 \quad 1$
Asn358,His5,

Tyr360, Try389,

Asn415, Cys416
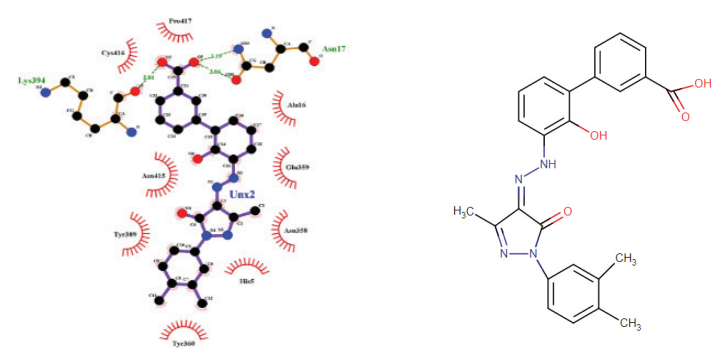

7 DB00444 Vumon $-9.9$ DB00872 Conivaptan $-9.9$

3

(2.81, 3.

$26,3.23)$
Asn17,Arg19, Tyr469, Arg22, Ser46, Met45, Asn432, Ile78, Val76, Asn77, Tyr18, Glu438
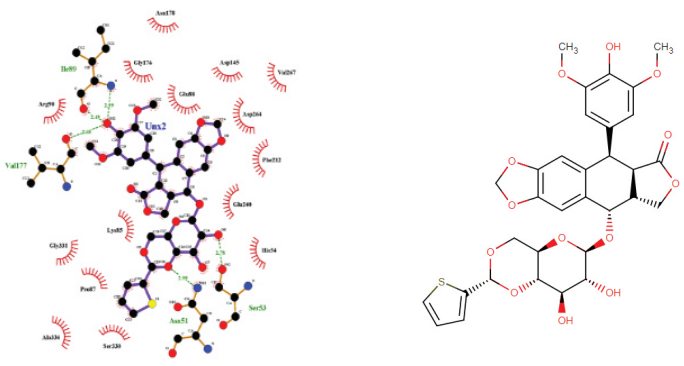

Asn178, Gly179, Glu88, Asp145, Val267, Asp264, Phe212, Glu240, His54, Ser330, Ala334, Pro87, Arg90
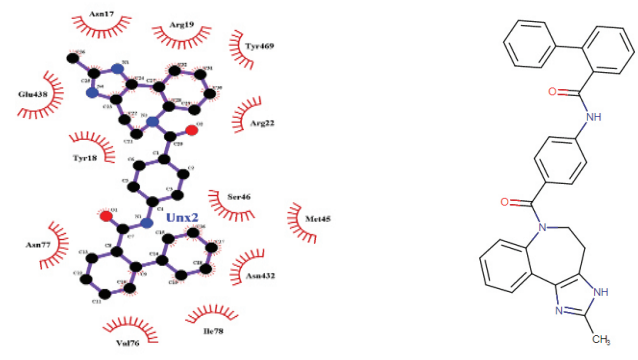

Val177, Gly176, Ile89, Phe212, Glu240, Glu88, Pro87, Thr296, Gln297, Glu300, Asp145, Asp264, Val267,
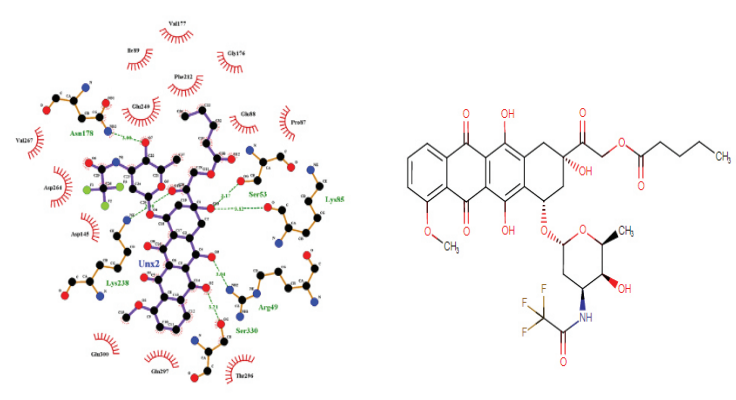

Arg49, Ser330, Asn51, Ser53, Lys85, Asp264, Pro87, Glu240, Gly176, Glu88, Phe212
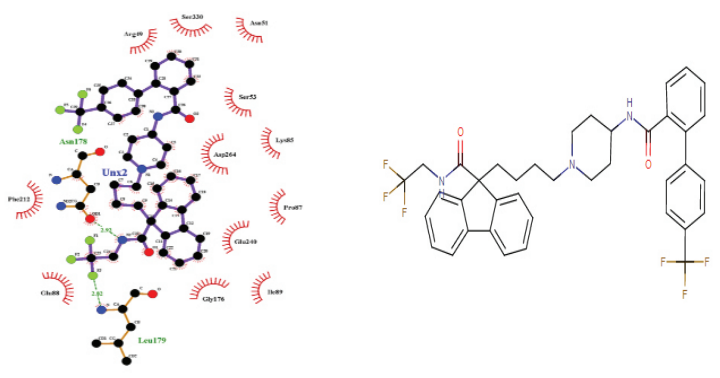


\section{CONCLUSION}

In this study, we used molecular docking to identify the top potent pyruvate kinase inhibitors among different FDA approved compounds. Structure-based drug designing and lead discovery were used effectively for computer-aided drug discovery. We screened in silico a large library of FDA approved compounds against pyruvate kinase protein, a vital enzyme for Leishmania survival. Ligands bounded with higher affinity to the target protein ranked by AutoDockVina score. The results presented here require clinical evaluation before the identified therapeutic agents can be used as anti-leishmanial drugs. The identified leads with the higher possibility of binding to the target protein would reduce the cost of biological testing.

\section{Code availability}

Data were analysed using Cytoscape and AutoDock softwares.

\section{ACKNOWLEDGMENTS}

This study was supported by the Proteomics Research Center in Shahid Beheshti University of Medical Sciences.

\section{REFERENCES}

1. Ahmadi N, Modiri M, Mamdohi S. First survey of cutaneous leishmaniasis in Borujerd county, western Islamic Republic of Iran. East Mediterr Health J. 2013;19:847-853.

2. Amiri-Dashatan N, Rezaei-Tavirani M, Ahmadi N. A quantitative proteomic and bioinformatics analysis of proteins in metacyclogenesis of Leishmania tropica. Acta Tropica. 2020;202:105227.

3. Amiri-Dashatan N, Koushki M, Rezaei Tavirani M, Ahmadi N. Proteomicbased studies on Leishmania. Journal of Mazandaran University of Medical Sciences. 2018;28:173-190.

4. Reithinger R, Mohsen M, Aadil K, Sidiqi M, Erasmus P, Coleman PG. Anthroponotic cutaneous leishmaniasis, Kabul, Afghanistan. Emerg Infect Dis. 2003;9:727.

5. Tiuman TS, Santos AO, Ueda-Nakamura T, Dias Filho BP, Nakamura $\mathrm{CV}$. Recent advances in leishmaniasis treatment. Int $\mathrm{J}$ Infect Dis. 2011;15:e525-e532.

6. García-Hernández R, Gómez-Pérez V, Castanys S, Gamarro F. Fitness of Leishmania donovani parasites resistant to drug combinations. PLoS Negl Trop Dis. 2015;9:e0003704.

7. Chawla B, Madhubala R. Drug targets in Leishmania. J Parasit Dis. 2010;34:1-13.

8. Amiri-Dashatan N, Koushki M, Abbaszadeh HA, Rostami-Nejad M, Rezaei-Tavirani M. Proteomics applications in health: biomarker and drug discovery and food Industry. Iran J Pharm Res. 2018;17:1523-1536.

9. Mondal S, Roy JJ, Bera T. Generation of adenosine tri-phosphate in Leishmania donovani amastigote forms. Acta Parasitol. 2014;59:11-16.

10. Louassini M, Foulquié M, Benítez R, Adroher J. Citric-acid cycle key enzyme activities during in vitro growth and metacyclogenesis of Leishmania infantum promastigotes. J Parasitol. 1999;85:595-602.

11. Fothergill-Gilmore L, Rigden D, Michels P, Phillips S. Leishmania pyruvate kinase: the crystal structure reveals the structural basis of its unique regulatory properties. London: Portland Press Ltd.; 2000.
12. Flórez AF, Park D, Bhak J, Kim BC, Kuchinsky A, Morris JH, Espinosa $\mathrm{J}$, Muskus C. Protein network prediction and topological analysis in Leishmania major as a tool for drug target selection. BMC Bioinformatics. 2010;11:484

13. Smith GR, Sternberg MJ. Prediction of protein-protein interactions by docking methods. Curr Opin Struct Biol. 2002;12:28-35.

14. Csermely P, Korcsmáros T, Kiss HJ, London G, Nussinov R. Structure and dynamics of molecular networks: a novel paradigm of drug discovery: a comprehensive review. Pharmacol Ther. 2013;138:333-408.

15. Amiri Dashatan N, Rezaie Tavirani M, Zali H, Koushki M, Ahmadi N. Prediction of leishmania major key proteins via topological analysis of protein-protein interaction network. Galen Med J. 2018;7:e1129.

16. Trott O, Olson AJ. AutoDock Vina: improving the speed and accuracy of docking with a new scoring function, efficient optimization, and multithreading. J Comput Chem. 2010;31:455-461.

17. Thomsen R, Christensen MH. MolDock: a new technique for highaccuracy molecular docking. J Med Chem. 2006;49:3315-3321.

18. Laskowski RA, Swindells MB. LigPlot+: multiple ligand-protein interaction diagrams for drug discovery. Washington: ACS Publications; 2011.

19. Batada NN, Hurst LD, Tyers M. Evolutionary and physiological importance of hub proteins. PLoS Comput Biol. 2006;2:e88.

20. Joy MP, Brock A, Ingber DE, Huang S. High-betweenness proteins in the yeast protein interaction network. J Biomed Biotechnol. 2005;2005:96.

21. Yu H, Kim PM, Sprecher E, Trifonov V, Gerstein M. The importance of bottlenecks in protein networks: correlation with gene essentiality and expression dynamics. PLoS Comput Biol. 2007;3:e59.

22. Tulloch LB, Morgan HP, Hannaert V, Michels PA, Fothergill-Gilmore LA, Walkinshaw MD. Sulphate removal induces a major conformational change in Leishmania mexicana pyruvate kinase in the crystalline state. J Mol Biol. 2008;383:615-626.

23. Rebollo J, Olivero-Verbel J, Reyes N. New agents with potential leishmanicidal activity identified by virtual screening of chemical databases: new agents with potential leishmanicidal activity. Rev Univ Ind Santander Salud. 2013;45:33-40.

24. Fairlamb $\mathrm{AH}$. Metabolic pathway analysis in trypanosomes and malaria parasites. Philos Trans R Soc Lond B Biol Sci. 2002;357:101-107.

25. Mutlu O. In silico molecular modeling and docking studies on the leishmanial tryparedoxin peroxidase. Brazil Arch Biol Technol. 2014; $57: 244-252$.

26. Rana S, Mahat J, Kumar M, Sarsaiya S. Modeling and docking of cysteine protease-A (CPA) of Leishmania donovani. J Appl Pharm Sci. 2017;7:179184.

27. de Carvalho Gallo JC, de Mattos Oliveira L, Araújo JSC, Santana IB, dos Santos Junior MC. Virtual screening to identify Leishmania braziliensis $\mathrm{N}$-myristoyltransferase inhibitors: pharmacophore models, docking, and molecular dynamics. J Mol Model. 2018;24:260.

28. Kothandan R, Sivaramakrishnan M, Sharavanan V, Sivasubramanian R, Rapheal VS. Molecular docking studies of phytochemicals against leishmania donovani trypathione reductase. Int Res J Pharm. 2018;9:6165.

29. Allen WJ, Balius T, Brozell S, Fochtman B, Jiang L, Therese P, Jr. McGee TD, Moustakas D, Mukherjee S, Prentis L, Singleton C, Telehany S, Zhou 
Y, Rizzo R, Case D, Shoichet B, Kuntz I. DOCK 6.9 Users Manual. Available from: http://dock.compbio.ucsf.edu/DOCK_6/dock6_manual.htm

30. Jones G, Willett P, Glen RC, Leach AR, Taylor R. Development and validation of a genetic algorithm for flexible docking. J Mol Biol. 1997;267:727-748.
31. Grosdidier A, Zoete V, Michielin O. SwissDock, a protein-small molecule docking web service based on EADock DSS. Nucleic Acids Res 2011;39(Web Server issue):W270-W277.

32. Rao SN, Head MS, Kulkarni A, LaLonde JM. Validation studies of the sitedirected docking program LibDock. J Chem Inf Model. 2007;47:2159-2171. 